\title{
Information Sharing Alliances in the Airline Industry: An Examination of Code Sharing Agreements
}

\author{
WONSEOK WOO
}

This paper addexises the issue of inter-organizational intormation-sharing alliances and their impacts on firm values from the perspective of inter-organizational coordinaton between parters in the airline industry setting. We investigate the shareholder wealth effects of incer-organizational informarion-sharing abliduks: arrangemacnts, using 131 code staring astocmones in the arline industry between 1981-1997. Iimploying evert scurly rxthodolugy, we find that the information-sharing alliances between similas partners did create positive value in tcrms of stock returns at the time of alliance announcentersts to major US airlines. Huwever, alliances between dissimilar partners resuled in significant losses of sharcholder value to the majur aidlines. Thiess: results strongly support our main hypotheses, that information-sharing alliances arc successful and the benefits of such alliances arc realized only when coxprotimation difficultics carn be effectively dealt with.

Kerizusts: inter-organizational information sharing alliances, evcot scudies. cude sharins, coordination

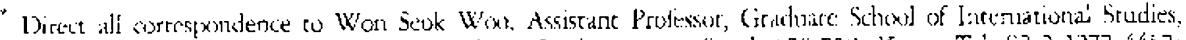

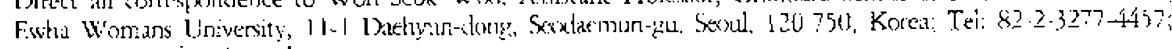
L.matil: wwootit cuthack:
} 


\section{INTRODLICTION}

A notable trend in industry in recent years is a persistent growth of alliances in such alliance arrangements. Information-sharing generated from the IT that mediates such alliances becomes the cors asset for these eypes of alliances. However: rescarchers have scarcely looked at the rolc of information sharing in creating stratchic advantages to the parrncers (Christiaanse 199). Moteover, no consistent patterns have been found when it comes on interorganizational information-sharing alliances aud thicir impacts on firm values. We arklress this issue from the perspective of inter-ntganizational condination betwecen partners in the airline industry setting.

In an effor to creare competitive prowess, airlincs often engage in indormation-sharing agrecments by sharing aisline codes (refered to as 'code sharing') in the computer resetvation systems. Code shiaring in airlines, offen referred to as in "IT-tnabled leading edge solution," occurs when one airline places a flighe code unto a service operated by another arline (Kao, Brown, aod Tornbohm 2000). With this context in mind, we tocus particularly on the following questions: Do information-sharing alliances add value to alliance partners: Lnder what conditions do such alliances create value, and whon do they not? Even when is is dear that some alliance atrangements may not ereate value for the partncess, why do birns engage in alliance arrangencuts?

We argue that the structural dimcnsions of inter-firm courdination benweerl partners trave significant roles in detcrmining the direction of stock market respunscs. Our study shows that code sharing agreenenes hetween "rrajor" and 'regional' airlines are ofter considesed in the stock maskes to be putentially clamaging to the furote value of the parricipating major airlines, showing a negative response wo the events. We argue that such results mighte $1 x$ : the conscquence of the "coordination trap:" an anomaly where coordination difficultics of the alliance excect the potential benefirs. In particular, we posic that buth coordination complexity and coordination dependency affect the coordination of the arrangements, impacting the stock market performance of partners. We use the event study methodelogy to investigare aboormal stok returns created by information-sharing alliances effected by code sharing agreernerts in the airline industry.

The paper is organized as follows. Cude-sharing agreemouts in the atrline indust ry are first intreduced. The subseguent section discusses the evaluation of an alliance in terms of steck market returns. Finally, (wi) different types of information-sharing agrecoments in the airline indedistry, code sharing among major-regional alliances and major-international alliances, are investigated, along with uther vatriables. The study: focuses on the stock matke responses for rrajor LIS airlines following ouck sharing announcements, since they are the ownets of Computer Reservation Systems (CRS) and often rhe initiators of the alliance arrangemernts. 


\section{INFORMATION-SHARING AILIANCES ANID THFIR PERFORMANCE IMPACTS}

\section{Computer Reservation Systems and Code Sharing Agreements}

Airlines have used various types of IT in order to gain control over their tevenue flows (Copeland and McKenney 1988; McFarlan 1984). Notable types include revenue management systems (RMS), computer reservation systents (CRS), distribution support systems (DSS), and other auxiliary systems. As shown in ligure 1, these systems are centered on CRS, either supporting the roles of CRS (e.g. DSS) or urilizing the information derived from CRS (e.g., RMS). Airlines use CRS for customer bonking, routing, and other services. CRSs are often connected to hotel reservation systems and car rental systems, making it possible for travel agents to provide a comprehensive set of travel services. In a CRS, eact member airline is assigned a unicue code for booking and routing purposes.

FIGLRE 1. INEURMATION SYSTEMS IN THE AIRUINE INULSTKY



Since each airline offers services for a set of routes, the strategic market posture of each airline has been limiced to coverage of air trivel routes. Airlines have uvercume this limitation by way of special information-sharing arrangements (code sharing) with other airlines, in which air travel routes of one or more arlines become available to each alliance partner by sharing airline codes in CRSs. ${ }^{2}$ International expansion of the trend for code sharing agrectnents has been rapid. According to Airline Business magazine, there were 389 alliances among airlines workdwicle in 1997 , a $40 \%$ jump since 1994.

\section{Inter-organizational Alliances and Stock Market Responses}

In inter-organizational alliances, wo or more autonomous organizations cooperate 
to pursuc joint achievement of their goals using their collective pool of resources (Contractor \& Lorange 1988; Parkhe 1993); One popular type of alliance other than the information-sharing alliance is the matketing alliance. Such alliances are eypically formed between partners producing complements in the market place (Bukklin and Sengupta 1993; Das, Ser and Sengupta 1993) and require sharing of information, though focused on downstream activitics such as sales and custoner service (Hagedowm 1993).

Despite alleged potential benefits, inter-organizational alliances ofters suffer from unexpected conscquences - about $55 \%$ of all alliances fall apart within three years and only $23 \%$ of these recover the costs of dissolution (Latraine 1999). In the recent past, a fow shudies have rocused on the implicarion of alliance arrangements on the firm value of pareners (e.g., Das, Sen and Sengupea 1998; lorange and Roos 1991; [Parkhe 1993). However, the results are mixed. Koh and Venkatraman (1991) found staristcally insignificant positive market reactions to announcements of strategic alliances. Das, Sers, and Sengupta (J94) 8) reported weak negative (statistically insignificant) masket reations to announcements of matketing strategic alliances.

Onc difficult consideration in stutying performance in alliances is measuring porformance itselt. Given the multi-faceted nature of partner objectives, performance can be difficult to measure in financial terms. Many successful alliances terminate because they are pre-programmed as such; sumbe fece-riders mat consider a short-lived alliance surcessful as far as their jutended objective (e.g. technology transter) is achieved (Ciulati lygs). The event study methed provides valual)le information in measurings the strategic values of alliance atrangemenes (Dos Santos, Peffers and Mauer 1993; Im er. Al. 2001; Subramani and Wakten 2001). In an efficient capital market, investors should recogrnize all the expected additions (or deductions) in future cash flow's resulting from an alliance artangement when it is publicly announced tlafortunately, cven in evene sruxty analyses, alliances do not secm to prodece positive responses all the time (Koll and Venkatraman 1991; 1)as, Sen and Senguipta 1998).

\section{Coordination Iependency and Requirements in Information-Sharing Alliances}

The current pesper primarily focuses on a very specific type of information-sharing alliance: code sharing agreements in the airline indusery. The paper areues that coordination dependencies between partners significantly affect ex-post costs of coordination and restructuring, thereby influencing the risk of default and prospective incone streanns. We argue that cask complexity and dependency (Malone and (rowston 199) 1 ) and information dependency (Milgron arkd Rolvers 1987; Rio. Chaudhury and Chakka 1495) catt iscate a 'courdianation trap,' where sx-post costs of cuordination and restructuring outweigh benefits of alliances.

When coordination dependencics are high, organizations need to bring together more coordination mechanisms and structural clements to control information and resource flow beween partners. When tasks and subtasks becween partncrs are complex 
and highly inter-dependent, more coutrol and coordination mechanisms are required and, as a result, coordinition difficulties increase. This is likely to lead co increasing information-processing costs (Galbraith 1977) and possibly a decline in performance (Pondy 1970).

When high dependency requires tight conrdination, partners tend to prefer more hiterarchical govertance mechanisms, such as joint venturc or cyuiry positions ${ }^{5}$, rather than using simple contractual forms of alliance. When hierarchical elements are introduced to respond to complex corrdination requirements, this may entail a sulssantial investment in structural tements (Crulati ant Singh 1998). Often-times. however, onc or bxth of the parties involved in the alliance are ecepured to go through extensive restructuring because of task and subtask complexities and dependencies (Crowston and Kammerer 1998). When this happens. inter-organizational pooling of resourecs draws more or less into the hicrarchical boundary of a partner. Morcover, the alliance could be cransiated later inco complete hierarchical arrangements, such as vertical integration or acquisitions (Peutzger 1996).

We argue that when this rype of conversion happsas, the stuck market perceives the risks associated with such changes and lirm risks and tuture income sercarms are considered from that perspective. In this coordination trap phenomenon, thers: is a rracte-off herween coordinationirestructuring requirements and benefits of alliance arrangements. The major and regional alliances in che domestic airline industry are good examples. Issues of task complexity and resource depondency, especially in terms of asymmetric intormation deferudency, offen require majos partners to invest heavily in coordination/restructuring efforts, which naly outwegh the benefits of the alliatnee artangements.

\section{HYPOTHESES ON CODE SHARING ALIIANCL PERFORMANCE}

In the airline indestr. code shating assecments are the foundation of information-slaatirig alliances. Two types of alliance arrangements are important in the domestic airline industry: 1) between major airlines and international airlines; and 2) between majors and regienals. Althougl these two alliances use (he same basic toul, i,ce, code sharing, for alliance formation, the nature of courdinition in these two types of alliances varies considerably.

The najor-international alliances ars chasucerized by horizontal alliances in which the pareners have comparahle objecrives, market siope, and operarional principles. The Vorthwest-KLM alliance arrangements clearly reveal the henefits of such alliance arrangenerests as is explaind by a torthwest executive: "80 percent of our stratcegies are very similar. We recently signed it transfer pricing agreement; we want to get

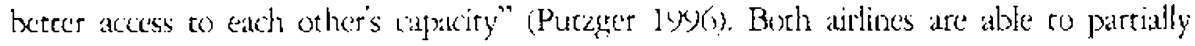
internalize its partner airline's flight information resoures and offer broader service options witheut incurring substantial investmentot risk, and thus financial distress. 
Economies of scale and scope econonies are high compared to the size of the uperational rics and investment requirentent, which is minimal. As such, investment in a partner's equity is not typical, although some alliances have later developed into mergers and arcuisitions. In contrast with major-segional alliances, in which many have later converted into mergers and acquisitions, major-international alliances are largely simple alliances without equity tics.

Major-regional alliances, on the other hand, represent vertical alliances in which hub operations (upstream activities in value chain) of major airlines are interconnected with the spike operations (downstrcam acrivities) of regional partners. The two have very different objectives in strategy, market scope, and operation. The objective of major arslines is to establish a sccure foothold in the local market by controlling regional competition. On the other hand, regional arrlines' objective is to driw on market power of the major partner in sarving in the regional market. (Oster and Pickrcll 1986). Major airlines face fierce competition from other nrajor airlines and intemational cartiers, whercas most regionals have only a few competitors in their serving markets (Philips 1996). Dute to differences in matket strategy and operational concerns, it is the major arlines that are responsible for the alliance to work. Information imbalances and task imbalances are problematic, as the entire opcration depends heavily on the major partners. After the alliances, regional partmers often need as be revamped in order to streamline the daily operations of major pareners (Philips 1)(3).

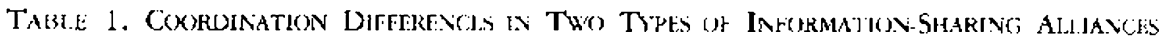

\begin{tabular}{|c|c|c|}
\hline Comrdination ateributes & Matistregronal alliances & Major-internationsal alliances \\
\hline 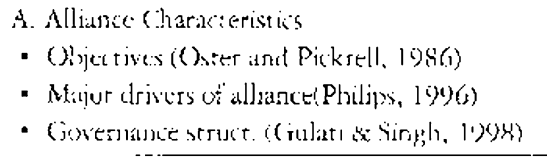 & 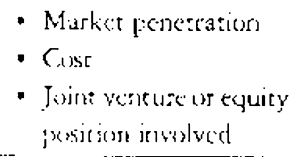 & $\begin{array}{l}\text { - Market Expansion } \\
\text { - Profit } \\
\text { - Simple illitances cojuity } \\
\text { posicion rarely iavolved }\end{array}$ \\
\hline 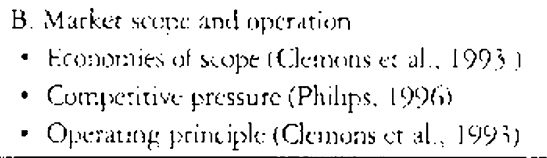 &  & $\begin{array}{l}\text { - Very high } \\
\text { - High fur boch } \\
\text { - Alnust identical }\end{array}$ \\
\hline 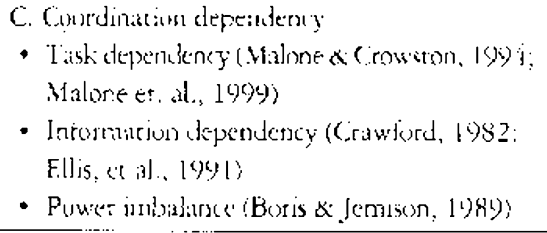 & 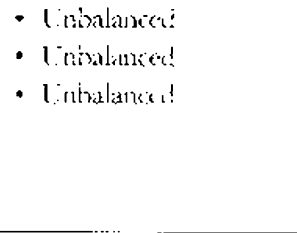 & $\begin{array}{l}\text { - Balanitid } \\
\text { - Balanied } \\
\text { - Balanced }\end{array}$ \\
\hline 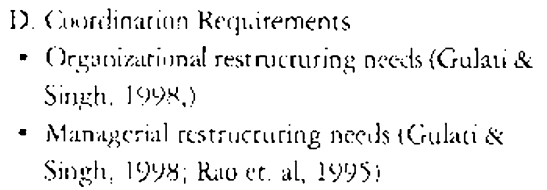 & $\begin{array}{l}\text { - High and imposed on } \\
\text { tike najur } \\
\text { - High and imposed in } \\
\text { the najor }\end{array}$ & $\begin{array}{l}\text { - Mediuter or lems } \\
\text { - High, but mutually } \\
\text { respunsible }\end{array}$ \\
\hline
\end{tabular}


Compared eo major-international alliances, major-regional alliances are generally characterized by comparatively higher coxodimation dependency in the task and sub-task environment, higher restructuring costs, and more vertical grovernance arrangrements. 'Table 1 shows the two types of alliances represcnting two different types of information-sharing ties, one (majur-regrional case) being vertical ties later being develesped into mergers, and the other (major-international case) being horizontal cies wichout equity positions. We arguc that such differences in coordination mecthanisms will be reflected in performance measures, and stock market responses to the alliance announcements will differ.

Hi: Code sharing argements botween lS majory and foretign imternationals will differ in



\section{Code Sharing Agrements between Major Airlines and Foreign Internationals}

As intemational air travel becomes the heart of competitive battle in the airline industry, strategic alliances are viewed as a low-risk strategy leading to international expansion. Information and resulnces of two dirlines are pooled together in order to create a syncrgy in which market accossibility of the partners is grearly expanded without incurring extra linancial costs. According to Surthwest, partner compatibility is the saliene actor in the suress of I'S majot-foreign international alliances (Putgzer 1996). Organizational goals and operational structure are similar, thercby reducing partner opportunism and ex pose courdiation costs of information and rezource sharing. Thus, post-alliance cordination is primarily an intormation systemitechnology issue (Putgaer 1996). Compatilvility berween partinets also minimizes the risk of uneven informational flow in terms of cuntrolling friformakion unfairly by a partner. "Iherefore: CS major and foreign international alliances lave low anticiparal comolination dependency as well as low ex-pose restructuring reguirements. As each allialue is arefully roven into the incernational web of alliances, chese alliances are known to create ex-post values to the partners. As sakth, pusitive stock ararket responses are expected. Therefore:

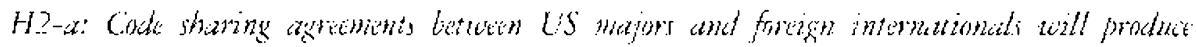

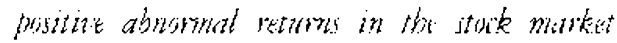

We also expect that, in genteral, the magroitude of an allisince rould cffect an information alliance atsh have an impdet on the futcure values of the partners (Ran (t al. 1995). There are two important variables that may represert the magnituke of alliances that would impact alliance performance: 1) the prescrec of multiple routes (vis. single route) covered in the agreement; and 2) the prescrec of other marketing contracts (vs. no orher contract) involved in the code sharing agreement. Becausc of the similarities in operation prixciples, narket strategies, and narket scope, coxordination requirements do not $5 \mathrm{cem}$ to incrase substantially in tandem with the number. 
of routes involved. Rather, the prescrese of multiple routes covered in the contrace may indicate the degree of involvement and acceptance of the agreement, which in turn may have an impact on the success of the partnership (Rin) et all 1995). Therefore, we anticipate that the presence of multiple routes covered in the corte sharing agreement is likely to amplify the relative impact on the stock price of the code sharing participants. Alliance arrangements containing other marketing contracts may indicate stratceic inest of the parners, showing clearly their seriousness and readiness for the alliance arrangements. Other marketing contracts include fiscyucnt flier mile programs, co-use of airport faciliries, advertising campaigns and so forth.

While these arrangements might increase coordination reguirements between partners with similar operation principles and strategies, they are not likely to be translated into major restructuring or ex-post rask coordination. We expect that the stuck market will reace positively to the news that thete are other marketing arrangements inerolved along with code staring agrecmonts. An introkluction of bew code sharing agrecments represents a cuantum change for airline partners. In contrast, an extensiont of, or an acklition ro existing agreements is only an incremental change for the airline partners. Therefore, we anticipate that stock market responses will be more positive to nate code sharing agreements than es the extension of, or addition to existing ones. These amplifications would occur because we expect the variables to moderate the relationship between IS major-international coxde sharing algreenents and stoxk market pexfornanec. Therefore:

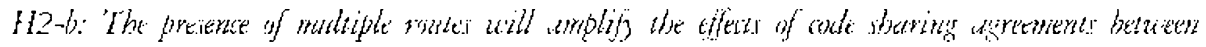

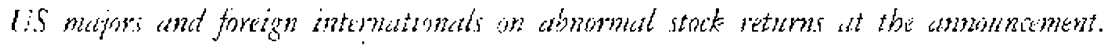

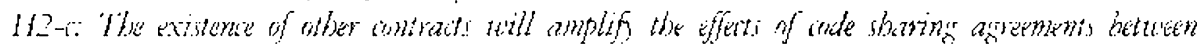

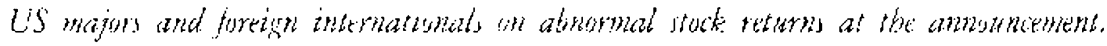

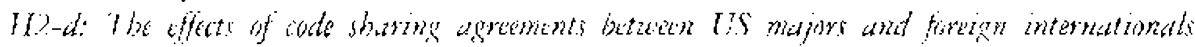

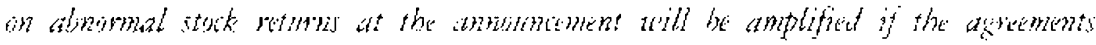

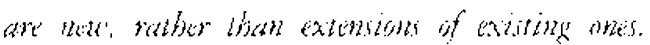

\section{Code Sharing Agreements between Major Airlines and Regional Airlines}

Code sharing agreements between major airlines and regionals are often problematic because partners have substantial differences regarding firm objectives, market scope, operating principles, and value chain activities as a whole. Regionals traditionally competed only in niche markets, while the major airlines have national and international prescnee. Accordingly, coordination depentency and expost costs of restructuring are likely to be high in this type of alliance. Negitive aspects of regional alliances lie also in the need for seamless bur flexible operation, and thus smoorth logistical collaboration between the partnets.

Unlike major-international alliances, which are usually hub and hub-operational contracts, major-tegional alliances icnvolve fine-tuning beeween hub encrations and 
spoke operations. Therefore, the alliance partners must share day-to-day operational details in the regrion so as to respond to shifting market demand promptly. Such reyuternents create an enommous operarional headache, which cannot tx. cisily resolved unless cighe operational relationships concurning information-sharing of daily activities are established.

No matter how detailed the contracts are, it is ofen difficule to achieve such a level of operational tics withour bringing all the exsurces under one governance structure (thate is vertical consolidation through mererers or acquistions). The detata risk of alliances is high, and to contain the coordination prohlens, majert airlines incroduce more hierarchical elconents and governance forms into the contract. A preliminary analysis of code sharing agrecments between major and regional found that in a substantial number of regional airlines, the major airtines either touk an cequity position or subsequenty açuired the alliance partners within a few years (Putzger 1996). It is also ohserved that about half of the regrionals that had cnecred into code sharing arreemenes with major airlines and had not heen subsespuently arcusured by the majors wert out of hessiness in the 1980) (Putegrer 1996). In order to protect their regional presence and partnership, the majors had to make a substantial invesoment in hierarchioal clements and cven internalize their investment through eyuicy position or acculsition. Therefore, it is likely that many of the majur-regional alliances have fallen inse the coordination trap, where, assticipatest coordination and restructuring difficulties outweigh the bencfits of alliances and, as a resule, market clements of the alliances are climinated subscquently.

W': expect that the riskis associated with high ex-post coordination and restructuring recpuircments will be refleced negarively in the stock prices of the alliance prormets, and also that when an equity position is involved, the stock market vicus it as a traditional hicrarchical consolidation and responds to it accordingly (Gulati and Singh 19987. 'Therefore: we anticipate a men-pusitive siock response for major parter airlines at the time of alliance announcencents.

 stork matkit profonises.}

In addition to the expectation that the stoct matret response at the time of conte sharing announcements berween majur-regional airlines will be negative, we anricipate that the presence of mulejple routes covered and the existence of uther contracts will adversely influence the abnomal stock retums of announcement dates. This expectation is related to the previous hypotheses (H2-b, c) in that rhe general magnitude of couk sharing agrecments. such as the prescnce of multiple routes covered and the cxistence of uther contrarts, will have an amplifying impact on the already presumed negative stock price response in the financial market. This would occur because we

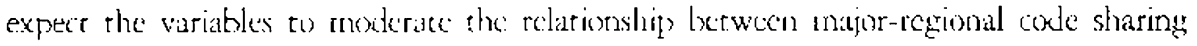
agrecmenes and struck mirket performalues.

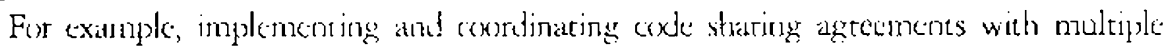


routes are more difficult than those with only a singte route in terms of achicving efficiency and sedmless operation. Investors will sespond more negarively in the case of cods sharing agreements with the presence of multiple routcs. Ws also expect that the stok market will respond more negatively to nen' major-regional code sharing ayreements than to the extcrision or addition of existing ones, because new agreements will create a preater perturbation in the stock market than existing ones (which are already common knowledge). Therefore:

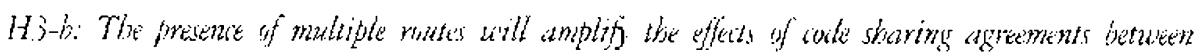

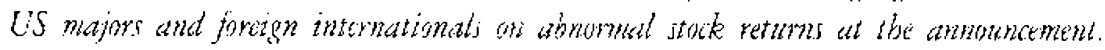

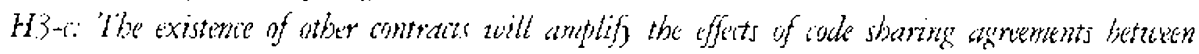

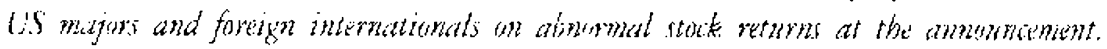
H.3-d: The effols of code shanns agrements betuen lis majors and fortign internationalis


cire wer, wather than extetirimis of existing wier.

Figure '2 summarizes our hypotheses and rescards model.

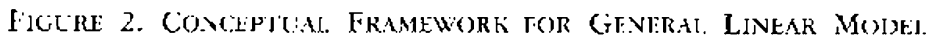



\section{DATA AND ANALYSIS}

The data was gachered by tracing all the code sharing agrecments macte in the airline industry and announced in Aviation Daily between January 1984 - December 1997. We used Aviarion Daily because it is the only compreherisive dialy in the airline industry and is commonly used as a data source fall announcements regarding 
aviation are first announcements?.

Data gathering involved the content-analycic technichue, using key words such as "code sharing," "cole share," "information-sharing agreement," and so on. More than 400 alliances among airlines worldwide were found, of which 170 cases included contracts in which major LS airlines were involved. Of these, only 131 cases had all the rcquired data. We hat eighty-seven cases for major-international arlines code sharing agrecments, thirty-five cases for major-regrional agreements, and ninc cases for other type of ingreements (major-major agreenuenrs).

In the data, cighry-seven argeements turo out to have more than one contract; thircy-six cascs have other maketing agreements along with the code sharing agreements; and 101 cases are found os be new initiatives.

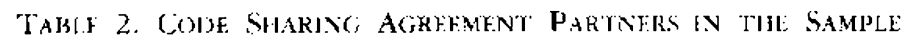

\begin{tabular}{|c|c|c|}
\hline International ajrline parturs & Miijur : itrlines & WationaliRegional airline partuners \\
\hline  & Amerilan & $\begin{array}{l}\text { Metru Airlinses } \\
\text { Lome Stat Airlues } \\
\text { Comminas Airsays }\end{array}$ \\
\hline Acres Mexiou & Antericas West & Mesil Mirlines \\
\hline  & Corstinctitial & $\begin{array}{l}\text { Cut Express: GP Express } \\
\text { Skywest, Gull Air }\end{array}$ \\
\hline 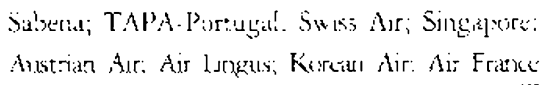 & Delta & Rensom Aislines \\
\hline & Eilscill & 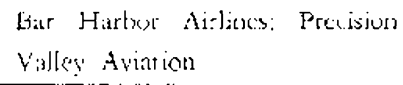 \\
\hline KJM: Chin: Air: Ansert: Air llK: Fatmongs & Virsclinest & 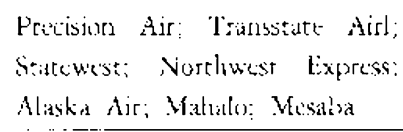 \\
\hline \multirow[t]{2}{*}{ Malilun. Hungarian Airlines; Adrua Aurlis:ers } & Ja' Ars & \\
\hline & Pieclnons & Brockwal hir \\
\hline 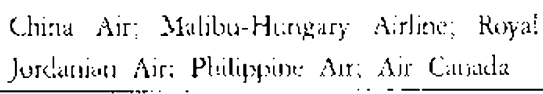 & IXA & $\begin{array}{l}\text { ler txpsess; Sratewesr; Poconos } \\
\text { Gull Arr; Wesc Air: Ajpha dir }\end{array}$ \\
\hline 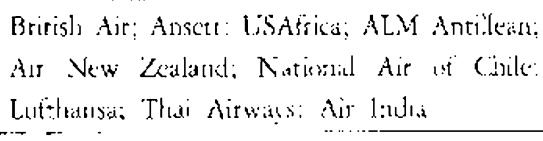 & Unitesi & 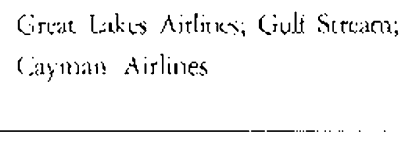 \\
\hline $\begin{array}{l}\text { All Nippon Airlines: } \\
\text { Bricish Airways: Qiasilliss }\end{array}$ & USAir & 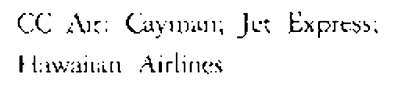 \\
\hline
\end{tabular}

Only the data that had US Airline involvement could be utilized because of the non-ayadiability of international stock price data, as well as non-availability of stock 
prices for smaller US recrionals because of their non-public status. Consecquently, code sharing agrecments sucts as internitional-international, international-bis regional, international-foreign regional, ctc., were excluded.

ii) test hypothesis 1, which asserts that steck market responses on the code sharing announcements between LS majursiforeign inemationals and LS majurs/rcgionals will be significantly differene, we calculdted the cumulative abnurmal stock recurns of each type of code sharing alliance for the day before and on the announcement diy (i.e. combined abnormal returns for two days [- - ,0]). Table 3 shows descriprive statistics for cach type of alliance.

Based on the normality of distributions of two abormal stock returns, the null and altcrnative hypotheses and tesc scaristic ate as follows:



$X, \ldots$ Mean of abnormal seock recurns lor the LS INI allianses during $[-1,0]$ $Y_{T}-$ Mean of abnormal stock recurns for the MA] REG allances during $l-1$, 0$]$ $u_{\mathrm{s}}=$ Expected mean of $\mathrm{X}_{\mathrm{m}}, \mu_{i}=$ Expected netan of $\mathrm{Y}_{\mathrm{n}}$

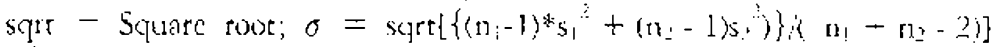

$s_{1}$ - Variance of abnormal stock recums for the US_INT alliances

s.: - Varriance of abnomal stexk returns for the MAJ_REG illiances

n. - Number of alliances between ES major and incernational airlines, i.c. LSS INT



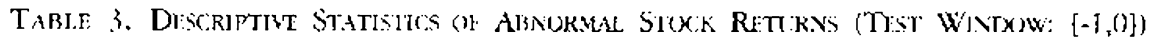

\begin{tabular}{|c|c|c|}
\hline & LS_INT & MAJ_REC \\
\hline Number ot Simples & 87 & 35 \\
\hline Nerage Abourmal Sroki Rerurns & $1.501 \%$ & $-0.979 \%$ \\
\hline 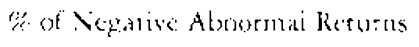 & 3.. $33 \%$ & $65.71 \%$ \\
\hline Highest Abnormal Rerutus & $20.56 \%$ & $1: .177 \%$ \\
\hline Lowcst donoromal Returas & $0.6 .3 \%$ & $-12.7(x)$ \\
\hline
\end{tabular}

lollowing Cody and Smith (1991), the General I.inear Model (GLM) method was used to analyze the dara and resc hypotheses 2 and 3 (Murphy and Myors 1999; litian ? $(X K)$ ). This was prefered to (OIS. sirxe the independent variables were dichotomous. The depeodent variatle is the "net abnormal narket retuens" of cath dirline, which is obtained using the Market Nudel.8 ithis is then used in our GIM model - the dependent vatiable that reperesents the nit abnormal return for the designated $i$ " period is denoted by the symbol Rl:Ti. The event study mothodology is brased on the assumption of efficient capital market rheory (Fama 1972), i.c., the market value of firns as reflected in their security prices fully reflect available intormation. As 
a result, whenever new information is made arailable to the market, the market adjusts the firm's value to reflect the changes in the present value of the cash flows and profits (Subramani and Walden 2001: Im, Dow and Grover 2001; Chaterjece, Richardson and 7.nud 2001). For cxample, the stock market reacts positively to the announcements of environment performance awards (Klassen and McLaughlin 1996) and guality awards (Hendricks and Singhal 1996). Here, the new information is the announcentent of cole sharing between LS major vs. international and regional airlines.

Event study methodology is common in finance atkd strategy literature (Patell 39)76; Brown and Warnos 1985 ) in inspecting the one day lefore-annousement and announcement day cffects for the calculation of abnormal stock market returns (i.c., $\{-I, 0\}$ ). Dos Santos, Peffers, and Mauer (1993) also adopted the two-daty announcenent effect in their empirical examination of the effects of announcements of IT investments on announcing firms' common stock prices. In addition to this return period, we also included in our analysis before and afrer-amouncement periods (i.c., $[-20,-2\}$ and $[* 1, \cdots 20]$ to sec if the announcement day effects can be isolated to the code sharing agrecment cecuts.?

The following varables indicated the types of agreoment (CS-LS_ $1 N T$ and MAJ_REC), presence of multiple routes awered by the contrace (ROT.TE), the existence of uther contracts made ilong with the colle-sharing agreement (CONTRiCT), and whether the agrement was new or nor (NEW). All the main variables are indicator variables. We used the cocling scheme of $1,-1$, and () to designate the indicator variables of [IS_INT, MAJ_REG and others such as MAJ_MAJ and REG_REG (Neter, Kutner, Nachtshein and Wasserman 1996). 1 " US INT was coded as $\vec{l}$ if the code sharing agreemene was made berween a $\mathrm{LS}$ major airline and a foreign airline. MAJ_REG was coded as .1 if the coste shitring agreetnent was made Letween a US major airline and a regional airline. () was assigned if the rode sharing agreement was between US major airlines or berween IS regional airlines (i.e., MAJ MAJ or RFG_RFG). The types of ayseetnene variables were considered along with the inecraction variables between the types of cote sharing agreements and the pesence of multiple routes covered, the existence of ocher concracts, and whether the ingrecment was new or rot, respectively. ROL'I'E, CON'RACI, and NEW variables were included to sec if these variables independently had any effece on the abnormal seock returns around the time of the code sharing announcements. The ROLIT: variable was coded o if the cole sharing igreternerit covered only one ronte (single route), and 1 if it covered more than sne routes (multiple routes)." 'Ihe CONIRAC'I variable was coded $[$ it a code sharing agrecenent had other arrangements, and () if not. The NEW variable was codect $I$ if an airline company did not have an alliance with the particular airline before, and of if the coute sharimg agrement was the extension ot, or addition to the existing code sharing contract between these airlines.

To verify hypotheses $\mathrm{H}_{2}-\mathrm{h}, \mathrm{c}$. and $\mathrm{d}$ and $\mathrm{H} 3-\mathrm{b}, \mathrm{c}$. and $\mathrm{d}$, we included interaction variables (II through I3). The GLM model is specifeed as follows: 
RET $_{1}=$ i (CS, ROUTH, CONTRACT, NEW, I1, 12, 13)

where $\mathrm{RET}_{\mathrm{i}}=$ Net abnormal return for the period $\mathrm{i}$

$C S=1$ if code sharing agreement is made between LS and foreign airline,

- I if code sharing agreement is made hetween LS major and a regional airline

0 if code sharing agrecmene is male between US major or betwers US regronal airlines.

ROLTE - 1 if there werc multiple routes covered in the conle sharing agrement. CONIRACT $=1$ if there exist other contracts made along with the costc-sharing agrement

$\mathrm{NEW}=1$ if the contract is made firse time (not expansion of existing contractsi). $11=(C . S \times$ ROLTF $) ; 12=(C S \times$ CONTRACT $) ; 13=(C S \times N E W)$

We also performed multiple comparison tests (LSD and Scheffe test: sce Table 5) in order to determine the direction of significance for the independent variables and interaction variables that are shown to be statistically significant.

\section{RESULTS}

We found that hypothesis 1 was strongly supported by the analysis shown in the previous scction. The test statistic was 2.50, which is stittistically significant at $95 \%$ conficterce level. This means that stok market responses on the cole sharing announcements berween US majors/toreign incernationals and US majors/regional airlines, which were measured by the abnormal stock returns during the day before and the day of announcement, were significantly different. That is, the average abnormal returns for the US_IN'l alliances at the cimc of cole sharing amouncements were significantly greater than those for the MAJ_RECi alliames.

Table 4 shows that the type of alliance was a statistically important variable in docermining the abnomal stock returns at the time of cixde sharing announcements. Further, the difference in means berween LS_NT and MAJ_REG was statistically significant and was the most critical tacer among the three types of alliances. The encan difference between MAJ. REG and other types of alliances, i.c., MAJ_MAJ and REG_REG combined was also statistically significant, but this difference camnot be considerced valid due to the lack of sanuples (there were only nine combined conde sharing cases in our sample for the MAJ_MAJ and REG REG alliances).

Hypotheses 2-a and 3-a are strongly supported, as the cumulative average abnormal returns (CARs) for the US najor-intemational type of alliance were positive (1.501\%) for the period $[-1,0]$ and staristically significant at,$<0.1 \mathrm{l}$ (vel, and the CARs for the US major-regional alliance were negative $(-0.979 \%$ at $p<0.05$ level. Ihis shows that code sharing agrecments were noc always considered value-creating stratenic decisions by investors. In fact. it seems that investors penalixes alliances between major and regional airlines by responding negatively to the cok sharing agreement 
news in the stock market. It is noteworthy that the aboormal returns of major airlines for the test periods $[-20,2]$ and $[-1,+20]$ for both US major-international and ISS major and regional code sharing dgreenents were not statistically significant. This means that the strong test results of abmormal stock teturns at the code sharing andouncements for the est period $[-1,0]$ are primarily due to the announcements of code sharing agreement event, and that these results around the announcemont dates are further substantiated by the weak results of rwenty days before and after the anmouncenent day.

The results of Least. Significant Difference (LSD) test and Scheffe test show that all the signs for the coefficients of almormal returns around the announcement date are as expeced (see Table 5). For these, we separated riajor-tegional alliances from major-international ones in urder to highlight the variance differences between the two. 'The code sharing arsecment between ISS major and nternational airlines yielded consistently posicive abnormal returns while that between LS najor and regional airlines genterated consistently negative abnormal recurns for the return period of $[-1,0\}$. This means that cole slaring agrements berwecn IS major and international airlines werc considered to be good news by investors. On the other hand, as we hypothesized in $\mathrm{H}_{3-a}$, we fousd that code sharing ayrecments between US major airlines and regional alrlines resuleed in significantly negative abmormal reaums for all of the dejendent variables.

As far as orther explanaton varjables are concerned. $x$ found an interesting pattern. ROU'YE and NFW variables combined with the IJS major-regional rariable had a statistically strong relationship wirh abnormal recurns during 1.1 , of. According w LSD and Schetfe test results. the means of abnormal returns were negative. This indicates thit the code sharing atreements between US major athd regional produced strong negative alnomal returns at the 0.05 level when they covered multiple routes in their conteaces. If the cote shariag agrecment was ncw, rather than an extension of an existing contract, this negatively influenced tat $p<0$. I levely stock returns of major airlines that wernt into the cude shasing astangements with regional airlines. These results suppore our hypotheses. H3-h and d. However, ROI'IT, CONTRACT, and NEW variables did not have a statistically significant impact on the ahnormal stock returns when they were combined with major-intermational alliances, even though the direction of their impact was positive according to the I.SD and Scheffe tests. This result shows that hyputhese's $\mathrm{H}_{2}-\mathrm{b}, \mathrm{c}$. and d were not suppored by the test results, and the ROUTF, CONTRACT, and NFW rariables did not amplify the abmurmal stock returns of major airlines at the time of code slating amouncements with international airlines (unsupported results are not shown in Table 5).

Event studies in prom literarure have consisently shown that there are some market imperfection effects regarding investors' reactions to strategically meaningful anmouncments due to pre-andouncement information spill-outs. Our study also has some implications with respect as this market efficiency issue - common arock investors reacted quickly on the annourcement of cokle sharing agrecments. The results also 
imply that there was litcle evidence of information spill-out shortly beforc or after the announcements (sce the resules of test periods $[-20,-2]$ and $\{+1 .+20]$ ). This strongly supports the argument for nuarket efficiency, which states that the stock price reflects all she information that is avalable to the public.


SHARIYY; AgRfFMfNTS ON THE STOCK MaRKET REIURNS

\begin{tabular}{|c|c|c|c|c|c|c|}
\hline \multirow{2}{*}{ Variahle Names } & \multirow{2}{*}{$\frac{\text { Days }}{\text { li-Value }}$} & \multirow{2}{*}{$\begin{aligned} & 20 \mathrm{t}(\mathrm{O}-2 \\
& \mathrm{P}_{\mathrm{r}}<\mathrm{F}\end{aligned}$} & \multicolumn{2}{|c|}{ Iays $-1,0$} & \multicolumn{2}{|c|}{ Days +1 w +20} \\
\hline & & & F-Value & $\operatorname{Pr}<\mathbf{F}$ & F.Value & $\mathrm{Pr}<\mathrm{F}$ \\
\hline $\ln (e x) e x$ & 0.92 & 0.1 .385 & $4.6^{\circ}$ & 0.0328 & 1.613 & 0,3039 \\
\hline (s) & $\therefore 32$ & $0.2:(4)$ & $5.96^{\circ}$ & 0.0221 & 0.03 & 0.9672 \\
\hline kotra: & 0.36 & (1.5.4.?.? & $5.15^{\circ}$ & 0.0250 & 1.58 & 0.2106 \\
\hline CONTRACI & $0.6: 5$ & (1) 1270 & 0.13 & 0.7161 & 0.32 & 0.571 \\
\hline$N$ NLE & 0.31 & 0.5812 & (1.). 17 & 0.6773 & 1.45 & 0.2306 \\
\hline CS*RUUllE: & 0.166 & 0.5183 & $2 . \mathrm{s}^{x}$ & $0.06(6)$ & 0.83 & 0.4403 \\
\hline CS*CONITRACT & 0.94 & 0.3952 & 1.4 & 0.2345 & 1.) (1) & 0.8350 \\
\hline CSkNiw & 0.27 & $0.7(11) 9$ & $3.3 !^{\circ}$ & 0.0390 & 0.01 & 0.9802 \\
\hline Matel & 0.70 & $0.23 \%$ & $2.5 \%^{\prime \prime}$ & 0.0056 & $0.5(i$ & 0.9021 \\
\hline R-siquare: & $0.0601 ?$ & & $0.19 \%$ & & 0.0435 & \\
\hline Ni. ols. & 131 & & 131 & & 131 & \\
\hline
\end{tabular}

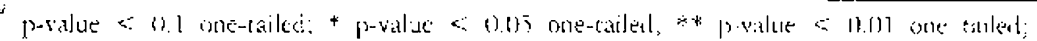

legend:



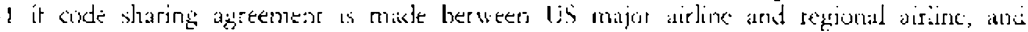

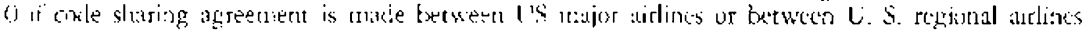



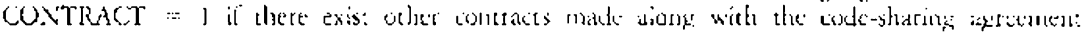

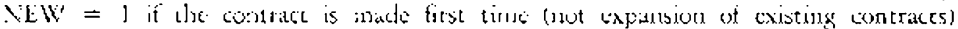

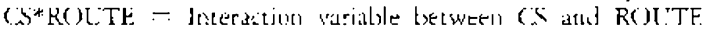

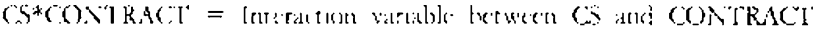



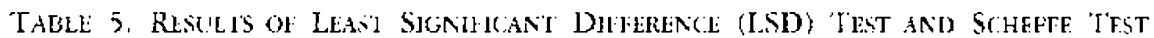

\begin{tabular}{|c|c|c|}
\hline & LSD Test & Soheffe lest \\
\hline Varlatile: V:unes & $0: 4 y-10$ & Dajs - i. 1 \\
\hline US_INT & .. & . \\
\hline$M A J K K C$ i & - & - \\
\hline ROU:TE & - & \\
\hline MAJ Rl: $(j * R())-\Gamma l$ & - & . \\
\hline$M A J_{-} \mathrm{RLG}$.NEW & - & - \\
\hline
\end{tabular}




\section{DISCUSSION ANI) CONCLLISION}

This paper investigated the shisteholder wealth effects of inter-nrganizational infurmation-sharing alliance arrangements, using code sharing agreements in the airline industry between: 1) IJS major airlines and international airlines; and 2) LS major aurlines and regional airlines. We hypothesized that the alliance berween cqually-balanced partners in terms of organizational size and information flow will create more value to the investors than the alliance between unbalanced partners. Our hypotheses were primarily based on the differences in coordination difficulties between alliances of balanced partners and that of unbalineced ones in terms of task dependency, information dependency, and power imbalance.

Previous studics have revealed that alliances might not always create positive stock markct returns to the partners. The researchers, however, did nor explore this anomaly. although studies sugrgest a strong possibilicy that alliances may represent bad newes for the investors (Koh and Venkatraman 1991; 0as, Sen and Sengupra 1998). The: current study is an cffort to investigate this question. It finds that: 1) information-sharing alliances such as code sharing agreements do creace positive abromal returns when costs of coordinating equally-balanced partners that engage in alliance contracts are relatively low; and 2) when pattriers possess differential levels of markct power, size, and information control, alliances scem to fail to create prositive valucs to the larger, major parchers, due to coordination and restructuring difficultes.

\section{Marketing Alliances: A Losing Game?}

It scems that corordination difficulties caused mainly by market scope and information asymmetry between partners impede syneryistic effects of information-sharing alliatoces in creating positive values to the partners. Dass, Sen and Sengupra (1998) note thar alliances are frefuerstly obsered in mature or declining industries where alliances might signal the troubles that partices experience. In addition, our findings suggest that partner asymmetry in terns of size and information control foreshadors a negative abnormal retum.

Then the question is: Why would firms cograge in information-sharisg alliance contracts, even when adverse stock market responses are expected? One of the reasuns might lie in the nature of shanges brought into the industry. For example, in the airline industry, information-sharing (through code sharing) agreements were the byproslucts of the on-going restructuring of the domestic as well as international airline industrics. The industry-widc shalie-out was so extensive that fout major aidlines (Easeterr), Braniff, Piedmont, and PanAnn Airlines) went bankrupr; more than $50 \%$ of regionals wirher went bankfupt or were acquired by of her (nusually major) airlines (Sterling 1986). By the ent of the 1980), most of the surwing regrionals entered into code sharing agrements (Fores 1990). Dirlines plunged into alliance artangenents in order to contain compecition ared instability, not exactly ksowing the impacts of 
alliances on the hotom line. Due to the instability that has characterized the airline industry, airlines tended to replicate what industry ladets were doing (DiMaggio and Powell 1983). " In fart, many major airlines used strategic alliances as a stepping-stone to subsequent acquisitions; in sume cases, major airlines acquired the partneritug regionals pratially at the time of agrcements. We found that the stock market penalized such alliances. This is consistent with some studies that reveal that certain strategic actions result in negative stock returns at the time of their announcements (Kim, Hwang and Burgers 19937. Sirower (1997) described this phenomenon as the "synergy trap."

Why can't firms learn frum others mistakes? It every firm is capable of learnings from others' mistakes, there should be no corporace decisions that yicld nogative returns at the time of announcennents, especially when the firms have had the time to wath what other firms behaved and performed. However, we are witnessing many corporate strategic decisions that consistently produce, on average, significantly negative returns. Some reseanchers alscribe this plenomenon to managers' hubris - their belief that ever though others failed, they are able to do better (Roll 1986; Sirower 1997). Are all the managers that decide to employ the above-nentioned strategies irfationil? 'The results of these event studies are only saying that these everats will, on average, produce negative response frum the stock market, and there are some companies that have positive abnormal teturns at the annouracenents. Information-sharing agrecments in this study need to be underscood in a similar context. It

\section{Implications}

The findings bear important implications for intormation alliance research in general, and for the literature on coordination prublerms lexween dissimilar parters in particular. Firse, earlier cheories on alliatuce performance may not be applicable tu contracts with unegually-balaned partners. Assuming that an alliance contract is an inter-firm cooperative arrangement wherein rival firms cooperate to achicve joint maximization of firm values, researchers have emplusized the importance of goal congruente among alliance partners and clcar hicrarchical arrangements for effective alliance manidgement (Burgers et al. 1993; Parkhe 1993). Special emphasis has been placed on promoting effective coopcration between taro partners (Hamel 19)1; Harrigan 1987; Osborn and Bambe 1990 ; Parkhe 1991, 1993). We fund that this eraditional perspective of altiances - seeing alliances as a coopcrative mechanism between partners - nady be tou natrow a perspective. In cases of mijor-regional alliances in the airline industry, goial incongnence is visible and the rclationship) is nor of conpcration, but of hicrarchical dominance.

Second, our findings imply that alliances characterized by hagh condination dependency and information asymmetry may be penalized by the nasket due to high risks of coordination and reorganimation. Strategic differences in terms of maket scope and operaring principles often spells for differences in structure and strategy, while the asymmecry in information contents offen requires partmers to undergo major restructuring 
for seamless flow of information resources. Under such circumstinces, whils alliances are arranged in order to buffer the uncertainties in the environment and contain the competition, internal risks prompted mainly by comdination problems berween ursequal partners might dominats: the possible benefies of the alliances.

Third. as explained by Das, Sen and Sengupta (1998), when information-sharing alliances occur in a maturing marke or during the industry shake-out, stock market does not always see an alliance arrangement as good nows. It may sec it as a sign of trouble, a prelude before a major shake-out. In fact, anajor and regionals alike used code sharing agreenents as a way to overcome maturing market conditions, i.s, ever incerasing competition, decreasing load factor and profinability, market instability duc to deregulation, ets. Under such circurnstances, firms eurn ineo unproven measures. Weak competitors wiold be forced oue and casualtics are incritable. Alliances with or among sud partuers do nut buffer emvirommenat uncertaintices and could be detrimental to the major partners that must boar such risks. In summary, when information-sharing alliances cantwe function as a lxundary spanning, buffering mectranism (which is the original design wi suct inter-organizational arrangements), they do more ham than good to the major parters. Intcraal risks assoxiated with such alliances become salient. Srock marker responses to suctu alliances are accordingly negative to these that should bear incernal risks, i.e., the major airlines in the current study.

There are curtain limitations in our study. First, we looked only at the airline industry, wish its own distinctive features - this can influence the scope of our rheory. Investigations un other industries should definitely help in terms of contirming the results we have in this study. Scond, to enhance external validity of the study, it would be most useful if the stock prices of international airline companies at the time of code sharing agreenent anoonncements were avaliable. Our belief is that the anmounciment of code sharing agreements wirh major LiS airlines should cause a positise impat on the market value of the corresponding international carriers. Another limitation is the difficulty of comtrolling for uther factors. This problem also exists for other cvent studics, which investigate infurmation cffects of major event annoucements on the value of tirms. In general, major extermal changes in the enviromentent should be controlled in the model as abnomal stock returns are calculated in terms of the difference between individual stexk returns and market recurns. However, it is inherently difficult to consides all other major events that are firm-specific in the event sudies. ${ }^{5}$

In summary, we beliewe that this study is annong the initial atrompts at addessing why inter-organizational informariun-shating alliance angouncements may produce negative abnormal returns in the stixk market to the major partners. 16 , Much of the previous researde has assumad drat alliance anmonuenu-nts produce pesitive abnomal returns. Hewewer, this study of the airline indusery has found that information-sharing alliances between unbalanced parters could he had news to the parenering major arjines. 


\section{REFERENCES}

Brown. S. J. and J.B. Warner. 1985. Using Daily Stock Returns: The Case of Event Stlidies. Joumal Finanial Lonomics 14: 3-31.

Bucklin. L.P. and S. Sengupta. 1993. Organizing Successful Co-marketing Alliances. Jizrnal of Markoting 57 (April): 32-46.

Burgers; W. P., C. W. L. Hill and W. C. Kim. 1993. A Theory of Global Strategic Alliances: The Case of the Global Auro Industry. Strategic Memagement Joumat 1ik(6): $419-32$.

Chatterice, D., V. J. Richardson and R. W' Zunud. 20y()l. Examining the Sharebolder Wealth Effeces of Announcements of Newly Created C.IO Positions. MS Omartert) 25(1): 43-70.

Christianse, Ellen. 199.1. Strategic Adrantage and the Exploitability of Infurmation Technology: An Empirical Study of the Effects of IT on Supplier-Distributor Relationships in the US Airline Industry. Timbersen Institute Reidonb Series 72 . Amsterdan: Thesis Publishers.

Clemons, E. K., Reddy, S. P. and Kow, M. 19y3. 'Ilx. Inopact of Information 'lexhnology on the Organization of Econornic Activity: The 'Move to the Midklle' Hylothesis. Jownal of Manayement lnformation System.r 10(2) (Decemberi.

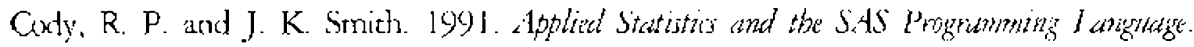
3rd edition. Fnglewood Cliffs, NJ: Prontice I Hall.

Cimtractir, F. J. and P. Iorange. 1988. Why Should Firms Cexperate? The Strategy and Econonic Basis for Cooperative Venturc. In Congerative Strategies in Intomational Bhines, eds. F. J. Contractor and P. lorange Lexington, MA: DC Heath.

Copreland, D. and McKenney, 1. 1988. Airline Restervation Systems: I.cssons from History. M1S Quturterl) 12(3) (Scptember): 353-70.

Crawtord, A. B., Jr. 1982. Compotate Eloctronic Mail-A Communication-Intensive

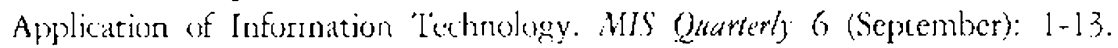

Crowston, K and Kemmerer, F. F. 1998. Conordination and Collective Mind in Software Requirements Development. IBAT Syrtemis Jommal 37(2): 227-45.

Das, S. P. K. Sen, and S. Sengupta. 1998. Impact of Strategic Alliances on Iirm

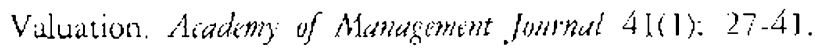

Dilkargio, P. J. and Powell, W. 1983. The Iron Cigge Revisiced, Institutional Isomomphism

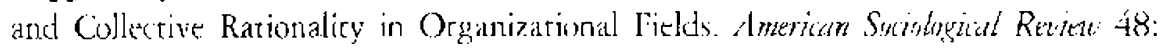
$147-(n)$.

Ixx Santos, Brian L., Ken Peffers, and David C. Mauer. 1993. The Inpact of Information lechnology Investment Annourkements on the Market Value of the Firm. Informutism Syitem:s Resumb at(1): 1-2j.

Elian, 5. N. 2000. Simple Fornus of the Best Lincar Linhissed Predictor in the General Lincar Regression Model. The Americm Statisticam 54(1): 25-28.

Ellis, C. A., Gihtss, S. J., and Rein, (r. L. 19)1. Groupware; Some Issues and Experiencets.

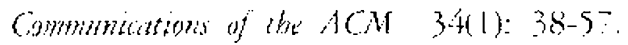


Fama, E. F. 1972. The Theng: of Fimeme. Hinsdale, 11l: Dryden Press.

[otos, Christoher P. 1990. Regionals Grapple with Lra of Maket Consolidarion.

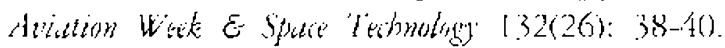

Fotos, Christober P. 1991. Regionals Airlines Wust Strengthen Ties to Major Partners

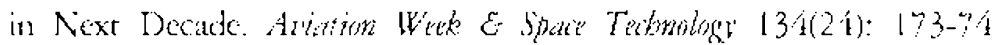

Galbrath, J, R. 197?. Omaniwatin Degzh. Reading, M.A.: Addison-Wesley.

Gulati, R. 1998. Alliances and Networks. Stratgii Managenent fommal 19: 293-317.

Gulati, $R$ and Singh, H. 19)8. The Architecture of Coxdination: Managing (iondination


Quaterly: $781-814$.

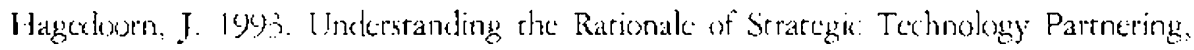
Interorganizarional Modes of Coopetation and Scctoral Differences. Stratesiz

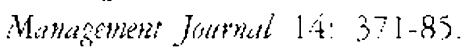

Hamel. G. 1991. Competition tur Compecence and Truer-Partoer Learning within


1 2: $83-103$

Harrigan, K. R. 1985. Strategit Alliances, Their New Roles in Cilobal Compertion.

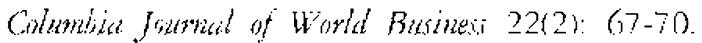

Hendricks, K. B. and V. R. Singhal. 1996. Quality Awards and the Marker Value of the Firm: An Empitical Investigation. Mantgement Sriencie $42(3): 415-36$.

Im, K.S., Dow, K. L. and Grower V. 2(0) I. Rescarch Kepote: $\Lambda$ Reexamination of IT Investment and the Markext Value of the Firm - An Event Study Methudologry. Informution Sybtemi Revatch 12(1): 103-17.

Kao I.., Brown R., and Tornbohm (.. 2000). Outsourcing in the European Airline Sector Takes Off. Gammer Gromi Repont (February).

Kim, W. C., P. Hwang and W. P. Burgers. 1993. Multinationals Diversification

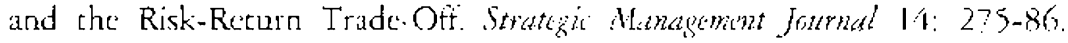

Klassen. R D. and McLatughlin, C. P. 19)6. The Impace of Environumental Management

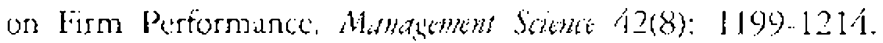

Kolı, J. and N. Venkataramman. 1991. Joint Venture Formations and Stock Marker Ractions: An Assessment in the Information Technology Sector. Aculemy of

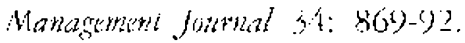

Iarraine, Segil. 1999. Alliance for the 2lst Century. Fxature Fxalleno' 16(10): 19.

Loringe, P. and J. Rows. 1991. Why Sumes Strategric Alliances Suceced and Other

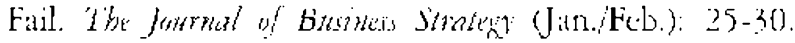

Malonc, T. M. and K. Crowston. 19)4. The Intcrdisciplinary Study of Coordination.



Nalione, T. M., K. Crowstom, J. Tee, B. Pentland at al. 1999. Touls fur Inventing Organizations: 'loward a Handbook or Organizational Processes. Memagembn Sicuce 15(3): $425-13$.

Milgrom, P. and J. Roberts. 1987. Informational Asymmetrics, Straccuic Behavior: and Industrial Organization. American Ecanmit Review $77(2)$ : 18.4-9). 
Murphy, K. R. and B. Myors. lyyy. Testing the Iypothesis that Ireatments Have Negligible tefferts: Minimum-Fffect $\mathrm{Tes}$ in the General Linear Model. Jum of



Veter, J., M. H. Kutoer, C. J. Nacheshein, and W. Wasserman. 1996. Applied Lintat Statitiat Modets. 4th ed. Chicago:MrGraw-HilliTrurin.

Osborn, R. N. and Baughn, C. C. 1990 . Foms of Inrerorganizational Crovernance for Mulcinational Alliances. Academy of Mamucmint Joumal 33: 503-19.

Oster, Clinton V. and Pickerll, Don H. 1986. Marketing Alliances and Compritive

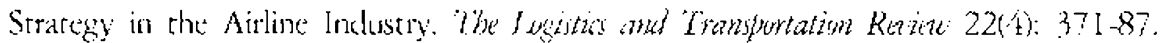



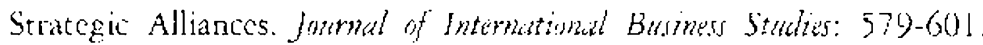

Patkbe, A. 1993. Strategic Alliance Structuring: A Game Theoretic and Transation

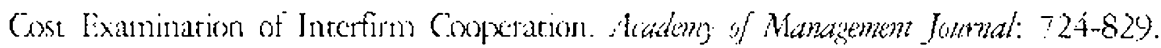
Patell, J. M. 1976. Corporate Furceasts of Earnings per Share and Stcek Price Bchavior:



Philips, Ledwatd 11. I9)6. Seamless Service, Jet Arraft Drive Competition anong Regionals. Ariation Week and Spute Tethology (Junc 3): 72-7í.

Pondy, 1.. R. 1970. Toward a Jheory of Internal Resourec Allocarion. In Potwey in Orzamzariom, ed. Maver $\mathrm{N}$. Zald. Nashville, TN: Vanderbile Lniversity Peess. Purzecer, Iant. 1996. Global Alliances Are Here to Sras, Airline of the liuture Will Be Conglomeration of Several Carriers. fomms of (immene (June 2.1 Specials).

Rat), H. R.. A. Chaudhury and M. Chakka. 1995. Modeling Team Proceses: Issucs



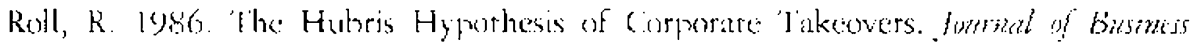
59 (Aprily: $19 \div-216$.


New York, NY: Free Press.

Sterlimgr N. A. I9s6. "l'he Cry is "Bail Our' as Regionals Atcempe to Stabilize. Neze: Englatel Baisincs! $8(6): 37-38$.

Subrumani, $\mathrm{H}$. and Walden, E. 2001. The Impact of E.Commerce Announcements on the Market Value of Firms. Information Syjtems Resemb 12(2): $135-54$.

Willamsin, O. E. 1975. Meskels and Hevambies. New York, NY: liree Press.

Williamson, O. E. 1981. The Modern Corporation: Origins, livolurion, Attributes. Jonmal of Eimomic Litatam 14: 15,77-68.

\section{ENDNOTES}

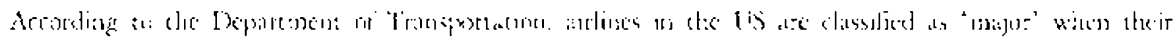

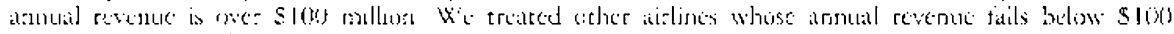



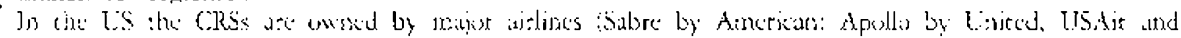

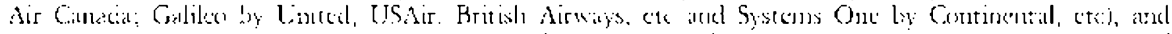

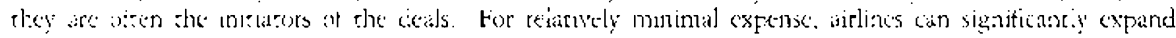




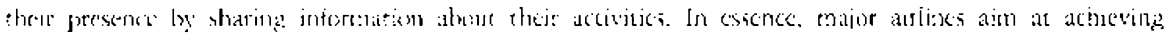

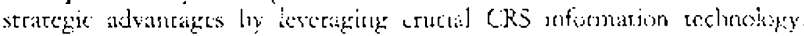

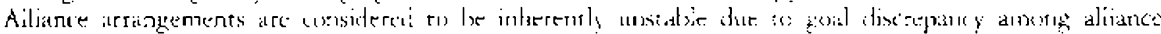



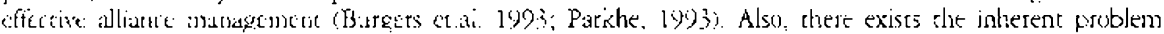

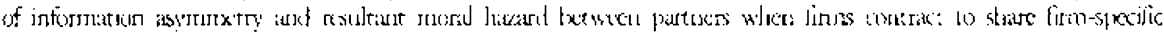

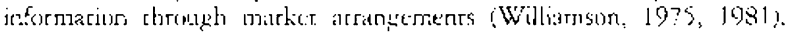

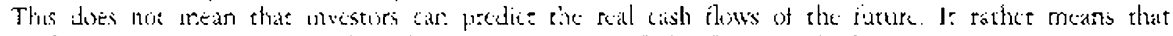

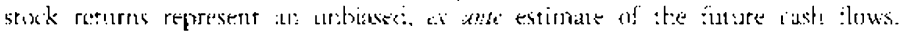

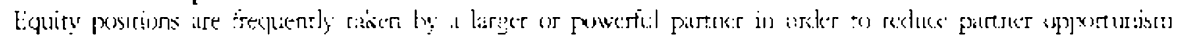

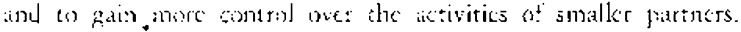

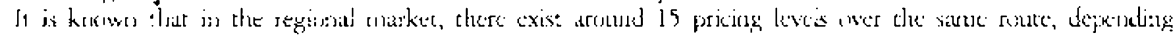

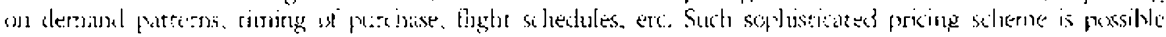

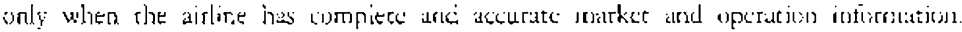



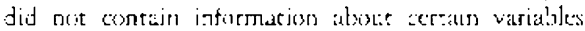

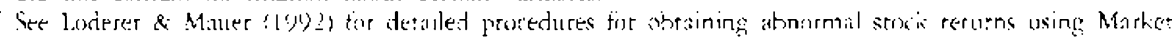
Mistel.

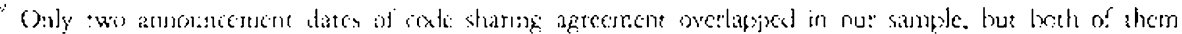

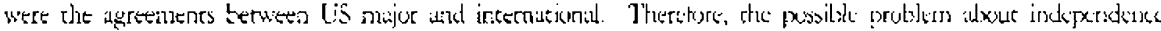

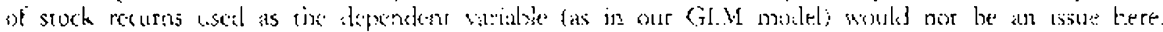


uf Mincesut is!

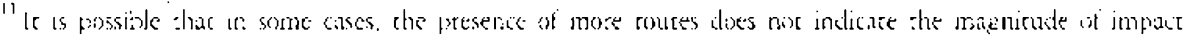

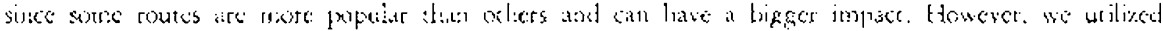

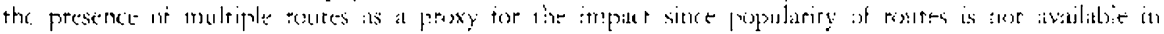
the Aviatem Daily and orler suarcies.



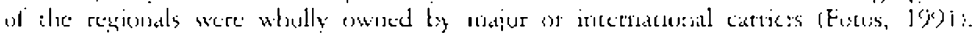

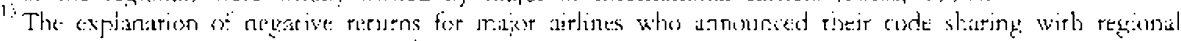

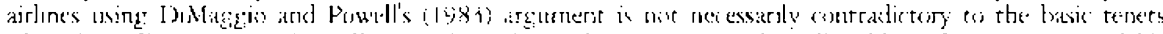

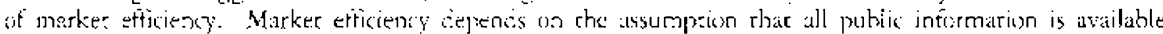

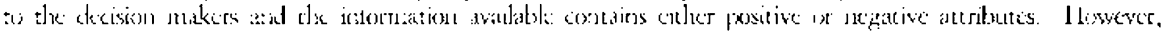

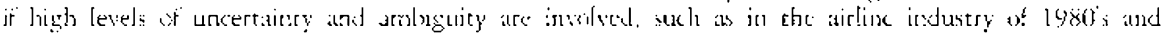



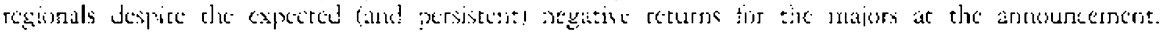


is

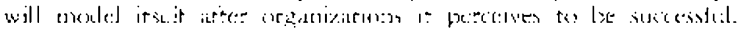

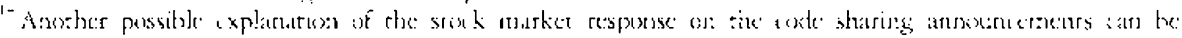

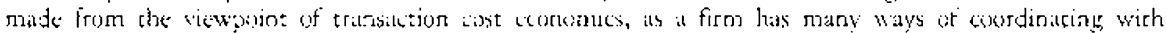







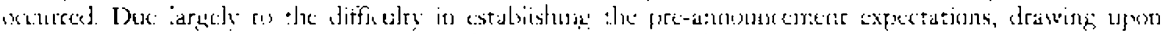

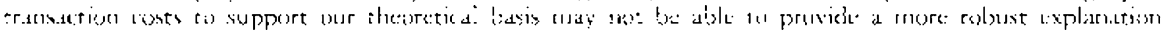

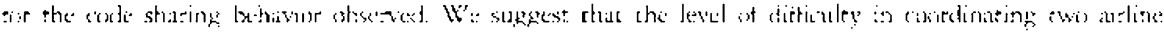

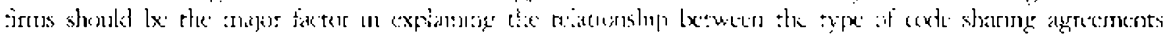
ansel aburusai stikt returts.

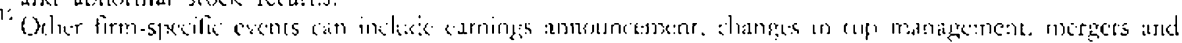


and we dhe bis ind any



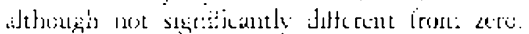

